NBER WORKING PAPER SERIES

WHAT DOES THE POLITICAL ECONOMY LITERATURE ON TRADE

POLICY (NOT) TELL US

THAT WE OUGHT TO KNOW?

Dani Rodrik

Working Paper No. 4870

\author{
NATIONAL BUREAU OF ECONOMIC RESEARCH \\ 1050 Massachusetts Avenue \\ Cambridge, MA 02138 \\ September ':994
}

I am indehted to Kym Anderson, Bob Baldwin, Dick Baldwin, Jim Cassing, Rob Feenstra, Arye Hillman, Steve Magee, Wolfgang Mayer, Doug Nelson, Sharyn O'Halloran, Edward John Ray, Ray Riezman, Ron Rogowski, Guido Tabellini, Mariano Tommasi, and especially Gene Grossman for their help in the preparation of this paper. This paper is part of NBER's research program in International Trade and Investment. Any opinions expressed are those of the author and not those of the National Bureau of Economic Research.

(c) 1994 by Dani Rodrik. All rights reserved. Short sections of text, not to exceed two paragraphs, may be quoted without explicit permission provided that full credit, including () notice, is given to the source. 


\author{
WHAT DOES THE POLITICAL \\ ECONOMY LITERATURE ON TRADE \\ POLICY (NOT) TELL US \\ THAT WE OUGHT TO KNOW?
}

\begin{abstract}
Three questions lie at the core of the large and distinguished literature on the political economy of trade policy. First, why is intemational trade not free? Second, why are trade policies universally biased against (rather than in favor of) trade? Third, what are the determinants of the variation in protection levels across industries, countries, and institutional contexts? These questions are handled only imperfectly by the existing literature. Current models treat trade policy as a redistributive tool, but do not explain why it emerges in political equilibrium in preference over more direct policy instruments. Further, existing models do not generate a bias against trade, implying that pro-trade interventions are as likely as traderestricting interventions. The greatest contribution of the political economy literature may lie in developing a better grasp of normative economic analysis--that is, in helping design policies. rules, and institutions.
\end{abstract}

Dani Rodrik

Department of Economics

Columbia University

420 West 118th Street

Room 1312

New York, NY 10027

and NBER 


\section{WHAT DOES THE POLITICAL ECONOMY LITERATURE ON \\ TRADE POLICY (NOT) TELL US THAT WE OUGHT TO KNOW?}

1. Introduction

Perhaps no other area of economics displays such a gap between what policy makers practice and what economists preach as does international trade. The superionity of free trade is one of the profession's most cherished beliefs, yet international trade is rarely free. Partly as a consequence, a large and distinguished literature has developed over the years on the political economy of trade policy. This literature has been well surveyed in a number of recent contributions, including Nelson (1989), Hillman (1989), Magee, Brock and Young (1989), Riezman and Wilson (1993a), Mayer (1991), Magee (1994), and Ray (1990).

This paper overlaps with these existing surveys, but also differs from them in being more specifically focussed on the questions to which the literature should be providing answers. In other words, I will review the literature from the perspective of what I take to be the interesting questions, and evaluate it by how well it measures against this yardstick. This kind of approach necessarily makes for a more critical perspective on the literature than is common. In particular, I will suggest that the political economy literature has lost sight of the very questions that have motivated it. My purpose in taking this approach is not to belittle the contributions made by the researchers in the area, who include some of the profession's best minds. The questions at issue are tough ones, and I hope that the difficulty of providing satisfactory answers will come across in my discussion. Rather, my primary goal is to refocus attention on these fundamental questions, and in doing so suggest interesting avenues of research for the next generation of political economy work.

To set the stage, I begin by setting out a general framework to assess the distributional consequences of trade policy (section 2). Using this framework as the background, the next 
section provides a guided tour of the leading approaches to formalizing the political economy of trade policy (section 3). I then tum to the questions of interest: Why is intemational trade not free? (section 4). Why are trade policies universally biased against trade? (section 5). What are the determinants of the variation in protection leveis across industries, countries, and time? (section 6). In the penultimate section, I discuss the economic consequences of viewing trade policy endogenously (section 7). A final section provides a brief summary and concludes the paper (section 8).

\section{General Considerations}

As illustrated in Figure 1 , in principle a politicat-economy model of trade policy must have four elements. First, it must contain a description of individual preferences over the domain of policy choices available to policymakers (box A). This is of course the easiest part of the exercise, insofar as much of trade theory is devoted to analyzing the consequences of trade policy for individuals who derive their incomes from different factors of production or sectors. Given an undertying economic model of the Heckscher-Ohlin or Ricardo-Viner type, and the presumption that preferences for policy depend only on self-interest, one can deduce individuals's polloy rankings on the basis of their factor endowments or sector-specific sxills. Second, the model must contain a description of how these individual preferences are aggregated and channeled, through pressure groups, political parties, or grass-roots movements, into "political demands" for a particular policy or another (box B). This step is considerably harder, as it involves a characterization of the modes of political organization as well as of the forms that political influence takes (lobbying, campaign contributions, voter registration, etc.). As we shall see, most models treat this component implicitly rather than explicitly. 
The next two components have to do with the "supply side" of trade policy. Here, the model must first characterize policymakers' preferences (box C): do politicians do what they do because they want to get re-elected? because they want to transfer resources to favored groups? because they have partisan preferences? or simply because they are interested in maximizing social welfare? To know how these preferences play out and eventually interact with the demands for trade policy, the model then has to specify the institutional setting in which policy takes place (box D): is it congress or the executive that sets tariffs? is the electoral system proportional representation or first-pass-the-post? are there intemational treaty obligations that rule out certain forms of trade interventions?

A satisfactory treatment of all of these issues is naturally a very tall order.' None of the existing models claims to provide a complete political-economic model, and appropriately so, since the end result would likely be intractable. The established practice is to take short cuts, and to leave implicit some of the elements discussed above. The success of a model must then be judged not only by the insights it provides, but also by the plausibility of the implicit stories that fill in the gap between what is explicitly modeled and what is left out.

2.1 A general framework. We begin by describing a general model of a small open ecsnomy, to serve as a backdrop to the specific models that will be discussed below. For simplicity, we assume all goods (but no factors) are tradable. On the demand side, we take individual preferences to be identical and homothetic (as most of the models also do). Each individual's indirect utility function can be written as $V(p) I^{h}$, where $p$ is a vector of domestic prices and $I^{k}$ is the individual's income. We will allow (some) domestic prices to differ from world prices $P_{i}^{*}$ due to trade interventions. Since we will focus on perfectly-competitive settings for the 
most part, these interventions can be thought of as price policies (tariffs, export subsidies) as well as quantitative restrictions (quotas).

On the supply side, we could use either a specific-factors framework or the HeckscherOhlin framework. In the former case, let there be m sectors, indexed by 1 , with each sector using one mobile factor (labor) and one sector-specifis factor with a constant-retums to scale technology. The retums to the specific factors can be captured by restricted profit functions of the form $\pi_{1}\left(p_{1}, w\right)$, where $w$ is the wage. An individual's income can now be expressed as

$$
I^{\Delta}=s_{L}^{b_{w L}}+\sum_{i} s_{1}^{D_{\pi_{1}}}\left(p_{1}, w\right)+\sigma^{\alpha} \sum_{i}\left(p_{1}-p_{1}^{*}\right) m_{1}
$$

where $L$ is the economy's aggregate labor endowment, $p_{i}^{*}$ are the world prices, $m_{i}$ are net imports, and $s_{l}^{n}, s_{1}^{n}$ and $\sigma^{n}$ are the individual's shares in the labor endowment, industry profits (or quasi-rents to specific factors) and net government revenue, respectively. The model is completed by the full-employment condition for labor

$$
L+\sum_{1} \frac{\partial \pi_{1}\left(p_{1}, w\right)}{\partial w}=0
$$

and by the resource-balance constraints

$$
m_{1}=-\frac{\partial V(p)}{\partial p_{1}} V(p)^{-1} \sum_{b} I^{b}-\frac{\partial \pi_{1}\left(p_{1}, w\right)}{\partial p_{1}}, \quad \forall i
$$

Note that we have used Hotelling's lemma and Roy's identity (which are the derivative properties of the profit and indirect utility functions) to state labor demand and commodity supplies and demands in terms of these functions.

In the Heckscher-Ohlin case, we have two goods and two factors, and the supply side 
of the economy can be summanized by using a revenue function of the form $R\left(P_{1}, P_{2}, K, L\right)$. An individual's income can now be expressed as

$$
I^{b}=s_{f}^{B} W L+s_{K}^{\Delta} I K+\sigma^{b} \sum_{1}\left(p_{1}-p_{l}^{*}\right) m_{1}
$$

where $s_{L}{ }^{n}$ and $s_{k}{ }^{n}$ are the individual's ownership shares in the economy's aggregate endowments of labor and capital, respectively. As long as both goods are produced, factor prices are determined by equality between unit costs and output prices in each sector. Letting $\theta(w, r)$ and $\phi(w, r)$ stand for the unit-cost functions for goods one and two, respectively:

$$
\begin{aligned}
& \theta(w, r)=p_{1} \\
& \phi(w, r)=p_{2}
\end{aligned}
$$

Resource-balance constraints are in tum given by

$$
m_{1}=-\frac{\partial V\left(p_{2}, p_{2}\right)}{\partial p_{1}} V\left(p_{1}, p_{2}\right)^{-1} \sum_{n} I^{b}-\frac{\partial R\left(p_{1}, p_{2}, K, L\right)}{\partial p_{1}}, \quad i=1,2
$$

Note that the model can determine only the relative price $p_{1} / p_{2}$, so that we are free to take either price as the numeraire and set it equal to any constant.

Now consider the decision problem of a social planner who does not care about income distribution. His problem is to choose trade policies (or equivalently, domestic prices) to maximize the aggregate real income of the economy. This can be achieved by solving the following problem: 


$$
\max _{p} W * V(p) \sum_{D} I^{\Delta}
$$

Let good $k$ be the numeraire and set $p_{x}=p_{x}^{*}$. Then it is straightforward to show that the soiution to this problem in both the specific-factors and Heckscher-Ohlin settlings consists of:

$$
t_{1} \equiv \frac{p_{1}-p_{1}^{*}}{p_{1}^{*}}=0, \quad \forall i
$$

This simply expresses the optimality of free trade in an economy free of distortions and in which distributional objectives can be camied out through lump-sum transfers or other policies.

The specific-factors and Heckscher-Ohlin models both imply that trade policy has stark distributional consequences. In the specific-factors model, these consequences are particularly strong for owners of specific factors, and can be deduced from the ownership pattem of individuais across the specific factors employed in import-competing and exporting sectors (see eq. (1]). Since $\partial \pi_{k}\left(p_{k}, w\right) / \partial p_{k}>0$, an import tariff or export subsidy in sector $k$ increases the retum to the specific factor in that sector, while harming retums to other specific factors through the induced increase in wages. In the Heckscher-Ohlin model, the distributional implications work along factor (rather than industry) lines and are described by the Stolper-Samuelson theorem. An import tariff raises the real retum to the economy's scarce factor and reduces the real retum to the abundant factor. An individual who is specialized in the scarce factor (relative to the "representative" individual) would be better off (see eq. [4]).

Neither the specific-factors nor the Heckscher-Ohlin models can account for the large share of world trade that is intra-industry. And since intra-industry trade can have 
distributional implications that are considerably less stark than either of these, we close this section by considering briefly a model with differer tiated products and increasing retums to scale (IRS).

Consider an economy with two sectors and two factors (labor and capital). Let sector one produce differentiated goods under IRS. In a symmetric equilibrium, each variety is produced by a different firm at an identical level and at price $p_{1}$, and free entry drives excess profits to zero. The second sector produces a homogeneous good under standard conditions. We assume consumers have a preference for variety along Spence-Dixit-Stiglitz lines and are (as before) identical in their preferences. Their indirect utility function can then be expressed as a variation of the one we have so far used, as $\gamma(\Omega) V\left(p_{1}, p_{2}\right) I^{b}$, where $n$ denotes the number of varieties available for consumption and $\gamma(n)>0 .{ }^{2}$ Each individual's income level is the same as that expressed in eq. (4).

In this economy fres trade will have some redistributive consequences along StolperSamuelson lines as long as its relative factor endowments differ from that of the rest of the world. However, the presence of IRS generates a motive for trade distinct from factorendowments considerations. Consequently, there will exist trade-intra-industry trade-even if there are no differences in relative factor endowments across countries. Moreover, what is particularty important from the political-economy standpoint is that this intra-industry trade will make everyone better off: it will increase the number of varieties available for consumption ( $\Omega$ ) without reducing anyone's real income $\left(V(.) I^{b}\right)$. Therefore, as long as intra-industry trade dominates factor-endowments-based trade, no individual will prefer autarky to free trade (see Helpman and Kugman, 1985, 190-195). However, this does not mean that trade is distributionalty neutral. Trade, and trade policy, will continue to have redistributive consequences as long as the home economy differs in its relative factor endowments from its 
trading partners.

\section{A Typology of Models}

Political-economy models generally take the specific-factors or Heckscher-Ohlin settings described above, and modify it in one or both of the following ways: (i) the objective function maximized by the policymaker is taken to show a preference for certain distributional outcomes, and hence to differ from that of the social planner (W); and (ii) individuals or lobbying groups are assumed to be able to take actions to shape the policymaker's

preferences. We now tum to discuss the leading models in the literature, emphasizing these two dimensions.

3.1 The taniff-formation function approach. The most direct way in which trade policy can be endogenized is to link the level of a particular trade policy instrument, say a taniff, to the amount of lobbying resources deployed by contending organized groups. This approacn was first used by Findlay and Wellisz (1982). In its simplest version, the model consists of a twosector economy where one of the sectors uses only labor under constant retums to scale. while the other one (which is also the politically-active sector) employs labor and sectorspecific capital (Rodrik, 1986). As long as the first sector is active, the constant marginal product of labor there fixes the economy-wide wage (say at unity). The tariff-formation function consists of a relationship of the form $t=t(L)$, where $L^{\prime}$ is the amount of labor used by the politically active sector in the lobbying process. The endogenous level of lobbying (and hence of trade protection) is given by the solution to the following problem:

$$
\max _{L^{1}} \pi\left(p^{*}\left(1+t\left(L^{1}\right)\right), 1\right)-L^{1}
$$


This story assumes that owners of the specific factor can perfectly coordinate their lobbying behavior and costlessly prevent free riding.

The Findlay and Wellisz (1982) model has two industry lobbies in a sector-specific factors setting, each deciding how much labor to devote to the lobbying activity. The resulting tariff level is expressed as $t=t\left(L_{1}^{\prime}, L_{2}\right)$, with $L_{1}{ }^{\prime}$ and $L_{2}{ }^{\prime}$ standing for the amount of labor devoted to lobbying activities by each of the sector-specific factors. The tarift is increasing in the import-competing industry's lobbying, and decreasing in the other industry's lobbying. There is diminishing retums to lobbying. A Nash equilibrium in the two groups' lobbying strategies determines the tariff. Feenstra and Bhagwati (1982) allow both labor and capital to be used in lobbying activities, but they focus on a case where only a single industry is politically active. While popular, the lobbying function approach has been criticized for treating the supply side of protection as a black box: the preferences of the politicians are not explicith stated.

3.2 The political support function approach. In this approach, the policy maker is assumed to be partial to political influence from an organized interest group representing a particular industry (as before), but is also assumed to care about the efficiency consequences of restricting trade. The policymaker maximizes a function which trades of the gains from protection to this industry against the losses to the general population. Letting $\mathrm{P}$ stand for the relative price of the organized industry. Hillman (1989) writes the political-support function as follows:

$$
W^{P S}=M\left(x(p)-\pi\left(p^{*}\right), p-p^{*}\right)
$$

The first argument captures the political-support motive in favor of the industry whose profit function is included in the maximand, while the second represents the efficiency loss (hence 
$M_{1}>0$ and $M_{2} \leq 0$ ). Note that both industry profits and overall welfare enter the political-support function not in levels but in deviations from the free-trade benchmark. The first-order condition for maximizing $W^{\text {Ps }}$ is given by:

$$
M_{1} \pi_{p}+M_{1}=0
$$

Since $M_{1}>0$ and $\pi_{p}>0$, an interior solution to this problem always requires that a positive level of protection be provided to the industry concemed ( $\left.p>p^{*}\right)$. This framework has been applied to numerous issues, including declining-industry protectión (Hillman 1982) and bilateral exchange of trade "concessions" (Hillman and Moser, 1995).

Van Long and Vousden (1991) provide a generalization in which political support depends explicitly on the income levels of different groups in a sector-specific factors economy. These authors distinguish between three groups in a two-good economy: owners of the specific factor in sector one, owners of the specific factor in sector two, and owners of the mobile factor (labor). Letting $h=1,2,3$ denote representative individuals from each one of these groups, respectively,

$$
\begin{gathered}
I^{2}=\pi_{1}(p, w)+\sigma^{1}\left(p-p^{*}\right) m_{1} \\
I^{2}=\pi_{2}(1, w)+\sigma^{2}\left(p-p^{*}\right) m_{1} \\
I^{3}=w L+\sigma^{3}\left(p-p^{*}\right) m_{1}
\end{gathered}
$$

where good 2 is taken to be the numeraire (so that $p$ is the relative price of good 1). The political-support function used by Van Long and Vousden (1991) then becomes:

$$
\tilde{W}^{P S}, \sum_{b} a_{b} V(p) I^{b}=V(p) \sum_{b} a_{b} I^{D}
$$


where $a_{n}$ are exogenous weights reflecting the politician's preferences over the three groups. Van Long and Vousden recognize explicitly that the shares of the three groups in tariff revenue $\left(\sigma^{m}\right)$ need not be constant, and will depend in general on the equilibrium prices. This approach can be viewed as the mirror image of the lobbying function approach: it makes explicit the objective function of the policymakers while leaving obscure the actions taken by influential groups to extract the desired behavior from them.

3.3 median-voter approach. This approach was piontered by Mayer (1984), who considered a direct-democracy model where the tariff level is determined by voting among the population. Using a Heckscher-Ohlin model, Mayer showed that each factor owner has an optimal tariff rate (possibly negative) whose value is uniquely determined by the individual's factor ownership. Let the exportable (good 2) be the numeraire with $p_{2}=p_{2}^{*}=1$ and $p_{1}=p=$ $p_{1}^{*}(1+t)=p^{*}(1+t)$. Assuming that tarff revenue is distributed in proportion to each person's share in factor income, individual h's optimal tariff rate is found by maximizing $V(p) l^{h}$ with respect to $p$. This yields:

$$
t^{\Delta}=-\frac{I}{p^{*} \partial m_{1} / \partial p} \frac{\partial \phi^{D} / \partial p}{\phi^{b}}
$$

where $l$ is aggregate income, $\phi^{n}$ is individual $h$ 's share in aggregate income, and $\partial m_{1} / \partial p<0$, In the Heckscher-Ohlin model $\partial \phi^{\phi} / \partial p>0$ if individual $h$ is relatively well endowed in the factor that is used intensively in the importable, and the strength of the effect is larger the more "specialized" the individual is in that factor. Consequently, such an individual's most preferted tariff will be strictly positive. Note also that the more open the economy to imports, and the more price sensitive is import demand, the lower the individually desirable tariff (or export 
subsidy).

As long as voters differ only along a single dimension (say, in their relative capitallabor endowment), the median-voter theorem can be applied to determine the tariff rate that would emerge from voting. If there are no costs to voting, the median eligible voter's decision is the outcome of majority voting. Therefore, under majority voting the endogenous level of trade policy is determined as if a policy maker maximized the utility of the median voter.

$$
W^{N}=V(p) I^{m}
$$

where $m$ denotes the median individual. Mayer (1984) also considers the specific factors case, to show that if there exists voting costs, a small industry is likely to gain protection because other interests may find voting against the proposed tanff increase is not worthwhile. ${ }^{3}$

This model is exemplary in that it is a fully-specified politicateconomic model, with no black boxes. The assumption of direct democracy greatly simplifies the institutional setting. obviating much of the detail normally needed. The downside, of course, is the lack of realism: in practice, trade policy is rarely determined by majority voting.

\subsection{The campaign contributions approach (Magee-Brock-Young). In the models mentioned} so far, the transfer of resources from special-interest groups to politicians does not pla". any direct role. Models by Magee, Brock, and Young (MBY, 1989, chaps. 3 and 9) and Grossman and Helpman (1992) have explicitly addressed the role of political contributions. In MBY, lobbies make campaign contributions to increase the probability that their favored political party wins at the polls. In Grossman and Helpman, campaign contributions are made to influence the policy stance of the incumbent govemment.

The MBY model adds two lobbies and two political parties (or candidates) to the 
standard $2 \times 2$ Heckscher-Ohlin model. One of the parties is assumed to be pro-trade, while the other is pro-protection. Each lobby represents one factor of production (capital or labor), and makes contributions to one of the two parties. (In equilibrium, it does not pay to split contributions.) Each party's election probability is increasing in the campaign contributions it receives but decreasing in the level of the policy intervention it commits itself to.

Formally, assume good 1 is capital-intensive and let $q$ be the probability that the procapital party is elected. Denote by $C_{K}$ and $C_{L}$ the campaign contributions made respectively by the capitalist lobby to the pro-capital party and by the labor lobby to the pro-labor party. Magee et al. express $q$ as $q\left(C_{k}, C_{6}, p_{1}-p_{1}^{*}, p_{2}-p_{2}{ }^{\circ}\right)$, where $q($.$) is increasing in own$ contributions and in the pro-labor distortion $\left(\mathrm{p}_{2}-\mathrm{p}_{2}{ }^{*}\right)$ and decreasing in the contributions received by the other party and in the pro-capital distortion $\left(p_{1}-p_{1}{ }^{*}\right)$. The pro-capital party selects $p_{1}$ to maximize $q($.$) , while the pro-labor party selects p_{2}$ to maximize $1-q($.$) . As for$ lobbies, they maximize the expected incomes of the factors they represent, net of campaign contributions. Letting $\left\{r_{k}, w_{k}\right\}$ represent the factor retums when the pro-capital party is in power and $\left\{r_{6}, w_{1}\right\}$ the factor retums when the pro-labor party is in power, the relevant maximands are

$$
\begin{array}{cc}
\max _{K} & {\left[q r_{K}+(1-q) r_{L}\right] K-C_{K}} \\
\max _{L} & {\left[q w_{K}+(1-q) w_{L}\right] L-C_{L}}
\end{array}
$$

The assumed strategic interactions are as follows: the two parties play Nash against each other, as do the two lobbies. But the parties are assumed to be Stackelberg leaders over the lobbies which contribute to them. This is equivalent to having parties move (that is, select 
their policies) in the first stage of a two-stage sub-game perfect equilibnum, with the lobbies moving in the second stage. The implication is that lobbies' contributions are intended to affect election outcomes but not party platforms. The model generates equilibrium levels of $p_{1}$ and $p_{2}$, i.e., an import tariff and an export subsidy. However, the framework is too complex to yield reduced-form solutions, short of making specific parametric assumptions.

The MBY model has been vigorously criticized by Austen-Smith (1991), both for its artificial restriction on the parties' platforms (either pro-export or pro-protection) and for its use of probabilistic voting without a rational-choice foundation. Mayer and $\mathrm{Li}(1994)$ have reworked the MBY framework lackling both criticisms. They provide better microfoundations for the MBY assumption that campaign contributions enhance electoral strength by modeling uncertainty explicitly. The full justification for the MBY model requires two-sided uncertainty: voters must not know exactly the policy preferences of the two parties, and parties in tum must be uncertain about some aspect of the voters' preferences. Mayer and $\mathrm{Li}$ also allow the parties to choose any policy they want. The result of these refinements is to weaken some of the MBY findings: it is no longer certain that the two lobbies will never contribute to the same party, for example.

3.5 The political contributions approach (Grossman-Helpman). The Grossman and Helpman (1992) model does not allow explicit competition among politicians. Instead, there exists a single incumbent who maximizes a weighted sum of total political contributions and aggregate welfare:

$$
W^{G H}=a \sum_{b} V\left(p, I^{a}\right)+\sum_{D} \lambda^{b}(p)
$$

where a $(>0)$ is the relative weight placed on aggregate welfare, and $\lambda^{h}(p)$ represents the 
contributions. ( $l^{n}$ refers to individual incomes before political contributions.) The undertying economic model is that of a small open economy, where the wage is fixed to unity due to the presence of a numeraire sector whlch uses labor alone. There exist $n$ additional sectors which use labor plus a specific factor. Some of these specific factors are represented by lobby groups. Each lobby presents the incumbent with a contribution schedule, mapping the policy vector (restricted to trade taxes and subsidies) into a contribution level. Letting $H_{i}$ stand for the set of individuals who own some of the specific factor used in sector $i{ }^{5}$ the lobby representing sector $i$ makes contributions amounting to $\Lambda_{i}(p)$, where

$$
\Lambda_{1}(p)=\sum_{b \in H_{s}} \lambda^{b}(p)
$$

Grossman and Helpman restrict individual preferences to the form $V\left(p, l^{n}\right)=l^{n}-\delta(p)$. Each lobby wants to maximize its membership's dtility (net of contributions). Therefore the lobbies' problem consists of selecting $\Lambda_{4}(p)$ to maximize

$$
V^{1} \equiv \sum_{b \in R_{1}}\left[I^{b}-\delta(p)\right]-\Lambda_{1}(p)
$$

The incumbent govemment takes these contribution schedules as given and maximizes $W^{\text {oH }}$ (eq. 17) accordingly. Note that lobbies commit to their contributions before policies are selected. In contrast to $\mathrm{MBY}$, then, political contributions are intended to directly influence the policies selected by the policy maker."

An equilibrium consists of a set of contribution functions $\left\{\Lambda_{i}(p)\right\}$ such that each of these maximizes the joint welfare of the lobby's membership given the schedules of other lobbies and the anticipated decision rule of the govemment, plus a vector of domestic prices which maximizes $W^{\mathrm{H}}$. Grossman and Helpman (1992) rely on results from Bemheim and 
Whinston's (1986) work on common agency to show that the equilibrium tariffs (or export subsidies) take the following form (provided the contribution schedules are differentiable around the equilibrium point):

$$
\frac{t_{i}}{1+t_{i}}=\frac{\zeta_{i L}-\alpha_{L}}{a+\alpha_{L}} \frac{x_{i}}{m_{1} \epsilon_{i}}
$$

where $\zeta_{\text {di }}$ is an (exogenous) indicator that equals one if industry îs represented by a lobby (and zero otherwise), $\alpha_{1}$ is the (exogenous) share of the population that is represented by lobbies, $x_{1}$ is the domestic output in sector $i_{\text {, and }} \varepsilon_{1}$ is the import demand or export supply elasticity (defined as a positive number for the former and a negative number for the latter). ${ }^{?}$ The protection received by a sector is higher when it is organized, when its output is high relative to compeling imports, and when the price responsiveness of the corresponding trade flows is low.

This model is applied to a two-country setting in Grossman and Helpman (1993a) and to analyze the political viability of a free-trade agreement in Grossman and Helpman (1993b). The great advantage of the Grossman-Helpman framework is that it allows the endogenous derivation from first principles of the campaign contribution schedules of competing lobbies in a fairty general framework. Moreover, it does so without sacrificing tractability. On the other hand, the model is subject to the criticism that only a small part of lobbying activity in real polities takes the form of financial contributions." 
4. Why Is Intemational Trade Not Free?

The raison d'être for the literature on the political economy of trade policy is the need to provide an answer to the question posed by this section's title. How well does the literature fare in this regard? At one level, quite well. Each of the family of models reviewed above provides a particular story about how organized groups or individual voters can take political action to reinforce or alleviate the income-distributional consequences of trade flows. While the manner in which political influence is exercised differs across models, the conclusion in common is: trade is not free because politically-influential groups can be made better off by policy interventions in trade.

At a deeper level, however, this shared bottom-line is problematic, or at least incomplete. The reason has to do with the well-known argument that trade policy is a highly inefficient tool for redistributing income (see Dixit, 1985, for a broad treatment). Saying that trade policy exists because it serves to transfer income to favored groups is a bit like saying Sir Edmund Hillary climbed Mt. Everest because he wanted to get some mountain air. There was surely an easier way of accomplishing that objective!

To more concrete, consider the case of garment workers in the United States. Let us assume that these workers are politically influential (in the relevant sense), and that transfeming income to them is the politically efficient thing to do. Assume, moreover, that the political equilibrium requires the garment workers' lifetime wealth to be higher than what it would have been under unfettered market competition by $\$ x$. Now consider the following five ways of achieving this transfer. (i) a lump-sum grant of $\$ \times$ to every worker employed in the garment industry presently; (ii) the same lump-sum grant, but to future as well as present garment workers; (iii) a permanent employment subsidy to the garment industry which increases workers' lifetime wealth by $\$ x_{i}$ (iv) a permanent production subsidy to the garment 
industry; and $(v)$ a permanent tariff on imported foreign garments. By construction, garment workers should be indifferent among these possibilities. The rest of society, however, progressively becomes worse off as we move from option (i) to option (v).

The puzzle then is why the worst of these opt.ons-trade intervention-should emerge in political equilibrium. This apparently perverse outcome is not only puzzling, but also goes against the expectation, most clearty articulated by Becker $(1983,1985)$, that pressure groups will favor more efficient means of transfering income to themselves. The models discussed above are largely silent on this issue, since they explicitly rule out recourse to other policies besides trade policy. Put differently, the existing literature is largely a literature on the political economy of redistribution, and not of trade policy proper.9 The links with trade policy arise only in the special case wherein policymakers are assumed to have access to no other instruments beside trade interventions. ${ }^{10}$

This is not to say that the existing models cannot be manipulated to generate examples in which trade policy is used in equilibrium even when a choice of alternative, more direct instruments is available. I will mention such examples below. The point is that the leading models are not primarily aimed at addressing this question. Therefore, there continues to exist a serious gap in our understanding of what makes trade policy so politically efficient, as it must be judged to be by revealed preference, when considerably more direct means of redistributing income certainly exist.

The existing work suggests two broad avenues for reconciling the political efficiency of trade policy with its economic inefficiency for redistributive purposes. First, it is possible that tariff-equilibria are preferred because they entail less cost to relevant political actors, in part because their economic inefficiency may make them harder to use. Second, tariff-equilibria may emerge as preferred outcomes in models with in:smplete information because of 
informational reasons. I will take up each type of explanation in tum.

\subsection{Taniffs as a means of reducing costly redistribution. Return for a moment to the} discussion above about alternative forms of transferning income to garment workers. What allowed us to rank these policies in terms of payoffs to relevant parties (garment workers and the rest of society) was that they were each calibrated so as to transfer a fixed amount of income $(\$ x)$ to garment workers. But in a politicat-oconorny framework, this is an inappropriate comparison. After all, the amount of income that in equilibrium garment workers manage to extract from the rest of society is really endogenous. Depending on the policies that are available, and the rules of the game, the distributive gains to workers will change, as will the associated costs-lobbying, campaign contributions--incurred both by workers in the pursuit of these gains and by others in the attempt to avoid the transfers. Consequently, the preferences of the relevant actors for specific types of redistributive policies cannot be known ex ante, and will depend in general on the features of the model at hand. Nor can the social desirability of one type of policy be easily ranked against that of another, once the endogeneity of the process generating these policies is recognized (Rodrik, 1987). ${ }^{11}$

The earliest paper that 1 am aware of which gives concrete form to this line of reasoning is Rodrik (1986). The paper undertakes a comparison of two policy regimes, one in which a politically-powerful industry can lobby only for production subsidies and another in which it can lobby only for import tariffs. The crucial difference between the two policies is that production subsidies can be in principle firm-specific, while impont tanffs are not. In view of the free-rider problem associated with lobbying for tariffs, then, the endogenous policy equilibrium involves a higher level of transfers to firms when production subsidies are the only instrument available. This added redistribution can be large enough lo offset the by-product 
distortion of tariffs on the consumption side. Hence, citizens acting behind a Rawtsian veil of ignorance, not knowing their later position in society, may well choose a tariff regime over a subsidy regime.

Wilson (1990) has provided a more elegant model, with the same flavor. In his words, "a move to relatively inefficient forms of income transfers may reduce the total excess burden in the economy, because the greater inefficiency induces the politicians to lower their use of transfers" $(1990,242)$. The model has two candidates competing to win office, with the probability of winning increasing in own contributions and decreasıng in the rival's. The higher the level of contributions a candidate receives the higher the transfer he will have to make when in office. But these transfers are costly to the politician due to their dead-weight loss. If the two candidates behave in Nash fashion in pursuit of contributions, in equilibrium there is excess contributions and excess transfers compared to what could have been achieved if they had colluded. So restricting the efficiency of transfers alleviates this particular problem, reduces the transfers in equilibrium, and could even make both politicians better off (since politicians are assumed to also care about deadweight loss). In particular, the political equilibrium with tariffs is more efficient than the one with production subsidies.

In a similar vein, Grossman and Helpman (1992, section 6) show in their model that lobbies would not necessarily prefer the govemment to use more efficient means of transferring income to them. The reason is that when competition between lobbies is intense. each lobby is making a large contribution, yet at the same time its effect on policy outcomes is being cancelled by the equally large contributions of other lobbies. So lobbies may support institutions that constrain governments to transfer income as inefficiently as possible (i.e., through trade policy), thus inducing lower contributions by each of the lobbies. As in Wilson (1990), the counter-intuitive result is the consequence of wasteful competition among lobbies 
that cannot coordinate their actions. Put differently, more efficient transfers allow the incumbent to play off lobbies against each other more easily, and to collect more contributions (1990, p. 33).

As a final example of this kind of logic, consider the paper by Staiger and Tabellini (1987). In the Staiger-Tabellini framework, trade policy is the consequence of a benevolent government's incentive to provide "surprise" protection to workers adversely affected by a fall in world prices. Since, workers cannot be systematically surprised, however, the timeconsistent equilibrium involves excessive protection (in the sense that the govemment may have preferred to commit itself to providing no protection at all). In this context, a switch from a more "efficient" policy lool (production subsidy) to a less "efficient" one (import tariff) can make the govemment better off: the less efficient policy alleviates the time-inconsistency problem by making it less beneficial to surprise the workers.

In each of the above models, the comparison involves equilibria of different "policy regimes", where each regime is characterized by the use of a specific poticy (tariffs or production subsidies, say). What is often left vague is the political mechanism that governs the choice of one regime over another. One can think of this choice as being made in the first stage of a two-stage political economy model. This appears to be the implicit view in the previous papers, but the decision-making process for this first stage is not well specified in any one of them. The main contribution of the type of reasoning represented by these papers is to suggest that tariff equilibria do not necessarily generate more deadweight loss than equilibria in which more direct redistributive policies are used, once the political determination of the magnitude of policy interventions is accounted for.

4.2 Teriffs as informationally efficient policies. Most of the models discussed so far are 
complele-information models where uncertainty or asymmetric information plays no role. In particular, politicians are assumed to be perfectly informed about the characteristics of pressure groups and the latter in tum to have full information about the economy-wide consequences of policy choices. In practice, of course, neither of these assumptions is tenable. Some effort has gone recently into modelling the consequences of relaxing them, with a particular eye lowards generating a rationale for the use of inefficient redistributive polices such as trade policy.

Magee, Brock, and Young (1989) propose the principle of "optimal obfuscation" as an explanation for the existence of trade restrictions. They argue that indirect policies present a political advantage precisely because their effects are less likely to be observed by those who bear the costs. Their formalization, however, is incomplete and presents more questions than it answers. In particular, as Austen-Smith $(1991,82)$ has argued, "rational maximizers without complete information may nevertheless be able to infer sufficient information from the behavior of others to make the 'correct' decision." A satisfactory model dealing with this issue must incorporate explicit uncertainty and be built on information-theoretic foundations.

A recent paper by Coate and Morris (1993), although not concemed directly with trade policy, represents an important beginning in that direction. They construct a model in which voters have uncertainty both as to the motive of the politician (well-meaning or redistributive), and as to the efficiency of the indirect transfer. With regard to the latter, there exists some states of the world in which the less direct transfer is also the more efficient one. They show that under these conditions inefficient transfers will soinetimes be made. The reason is that politicians care about their reputations, and redistributive politicians will sometimes rather maintain their reputation (of not being redistributive) than make the efficient transfer (which will be recognized directly for what it is). In other words, "the reputational penalty for using the 
[inefficient] policy to make transfers is likely to be less than that for making direct transfers" (Coate and Morris, 1993, 25).

One important contribution of the Coate-Moris paper is its demonstration that both types of uncertainty are needed for inefficient transfers to be made in equilibrium: if all politicians were alike, then their type could be readily discemed from their behavior. So uncertainty about the efficiency of the indirect transfer is not sufficient. But note also that their model has only partial applicability to the issues at hand. Trade restrictions are economically efficient only for a large country and for "optimum tariff" reasons; it is hard to believe that there would exist much uncertainty in practice about the legitimacy of this motive. ${ }^{2}$ (Remember that the indirect redistributive policy must be efficient in some states of the world, and that the state of the world is not observed by voters.)

Feenstra and Lewis (1991a) consider the role of asymmetric information from the perspective of a benevolent govemment. Suppose the government wants, following a fall in the world price of importables, to make sure that noone loses. Suppose further that the government can observe nothing about the domestic economy, and therefore that it can neither target lump-sum transfers, nor ensure that the taxes needed to finance a production subsidy on import-competing producers are designed appropriately to leave no individual worse off. Under these conditions, an import tariff is an infomationally efficient policy because the tariff necessarily and automatically benefits those that lose out, while leaving noone worse-off relative to the initial situation. In particular, a tariff equivalent to the decline of import prices will leave everyone in the economy as well off as before, while generating some govemment revenue which can be redistributed. The tariff policy does not require the govemment to have any information about individual production and consumption levels. Feenstra and Lewis show that the optimal, incentive-compatible policy in this case is actually 
a non-linear tariff, with larger producers of the import-competing good being protected by lower tariffs.

4.3 Other explanations. In a series of papers, Mayer and Riezman $(1987,1989,1990)$ have considered the choice between tariffs and more direct redistributive policies in Mayer (1984)type models. In Mayer and Riezman (1987), they show that where voter preferences are based only on differences in factor ownership, production subsidies are preferred by the median voter to tariffs (as expected). In Mayer and Riezman (1989), they allow voters to differ on other dimensions besides factor ownership, namely in consumption preferences and in their treatment under income taxes. With multidimensional voting of this type, there is of course no unique equilibrium. We need an agenda setter to determine equilibrium, but with that included, the more inefficient tariffs can certainly arise as a possible equilibrium. Finally, Mayer and Riezman (1990) provide additional reasons for why tariffs may be preferred by certain voters in the same kind of framework: if income taxes are progressive, the cost of financing subsidies will be focussed on richer individuals, while the cost of the tariff is more broadly distributed among the population, leading to some individuals prefeming tariffs; a tariff regime may be less risky ex ante, since the range of ex-post optimal tariffs is smaller than in the case of subsidies, resulting in risk-averse voters prefeming the former.

\subsection{The Choice Among Altemative Trade Policy Instruments. There aiso exists a related} literature that analyzes the political choice between tariffs and other trade policy instruments (mainly VERs). Hillman (1990) discusses how non-tariff bamers such as VERs and trigger price mechanisms can be viewed as arrangements that benefit producers in both exporting and importing countries at the expense of consumers. Hillman and Ursprung (1988) model 
how VERs can be preferred to import tariffs by both domestic and foreign producers, and therefore can emerge in a political equilibrium where each industry makes campaign contributions to their respective domestic politicians. Feenstra and Lewis (1991b) provide a model in which VERs are an efficient response to the following problem: when domestic political pressures are not directly observed by trade partners, each country may have an incentive to exaggerate the political pressure at home, so as to jack up its protection; therefore, "the transfer of quota rents [through VERs] can play a useful role in ensuring that countries do not exaggerate the political pressure for protection" (1304).

4.5 Summary and evaluation. The collective effect of these papers is to weaken considerably the presumption that direct redistributive policies should be politically more efficient than trade interventions. However, the reader would be fully justified if s/he is left uneasy about how well the literature has tackled the task at hand. The results discussed above tend to be too narrow and specific to account for what is essentially a universal phenomenon: the preference of political systems to use trade interventions to generate or sustain distributional outcomes. Of course, trade policy is not the only, or even the most important, mechanism of redistribution used by govemments. But practically all govemments apparently use it for that purpose. A sufficiently general and convincing explanation for this phenomenon has yet to be formulated. Part of the problem is that the literature has largely relegated the preference for trade policies to a side show. The papers discussed in this section represent a tiny minonity within the literature on the political economy of trade policy, and even in some of these the question of policy choice is an afterthought. This is also reflected in the small role attached to the question in existing surveys. In Hillman (1989), for example, the chapter entitled "Political Choice of the Means of Protection" focusses its analytical core on the choice between tanffs 
and quotas, and not on the choice between these and more efficient distributive policies. In Magee, Brock, and Young (1989), the preference for trade policies over other policies is not discussed until the very last chapter. Clearly, the literature needs a shift in focus.

\section{Why Are Trade Polkcies Blased Agalnst Trade?}

Let us assume for a second that the existing literature provides a satisfactory explanation for the prevalent use of trade policies for distributive purposes. We now confront a second, equally important puzzle: why are trade policies almost atways biased against trade, rather than in favor of it? That is, why is trade policy systematically used to transfer resources to import-competing sectors and factors rather than to export-oriented sectors and factors?

That there exists a systematic bias should be obvious: there is no country that I am aware of where the net effect of commercial policies is to expand rather than contract trade. ${ }^{13}$ This is also reflected in the fact that multilateral (as well. as bilateral) trade negotiations typically focus on eliminating bamiers to trade rather than artificial inducements thereon. The few case studies that focus on the political activities of export-crented interests take it for granted that the focal point around which such interests coalesce is free trade, not export subsidization (see Destler and Odell, 1987, and Milner, 1988). It is not clear why this should be so, when the analogous benchmark for import-competing interests is protection. ${ }^{14}$

On this puzzle we get very little help from the literature. Consider the leading models. The tariff-formation function approach a la Findlay and Wellisz (1982) essentially assumes the problem away by stipulating that sectoral interests lobby for tariffs but not export subsidies. The political-support function approach a la Hillman (1982) generates the asymmetry by assuming that the policymaker desires support from import-competing interests but not from exporting ones. The other leading approaches do not introduce artificial asymmetries, and 
therefore generate no presumption that the equilibrium trade policy is a tariff rather than an export subsidy (although their language often suggests otherwise). In Mayer (1984), for example, the equilibrium trade policy would consist of an export subsidy when the median voter is relatively well endowed with the economy's abundant factor. ${ }^{15}$

Let us look at this question more closely using the Grossman and Helpman (1992) framework. As shown in equation (20), the level of support (import taniff or export subsidy) received by an industry depends in this framework on a number of features, including whether the industry is organized or not and the size of its trade elasticity. Leaving aside artificial asymmetries along these two dimensions, the model predicts that industries with high levels of output relative to their respective trade volumes receive more protection. To see what this implies, let us consider the case of a single import-competing and a single exporting industry. Since trade must be balanced, the question of which industry gets more protection then boils down to which industry has the higher level of output. And if comparative advantage carries any force, countries will tend to specialize in their export sectors; that is, they will have larger export sectors than import-competing sectors. The unfortunate implication is that we should observe a bias towards export subsidies, and not import tariffs! Indeed, Levy (1993a) has shown that in a symmetric, two-country Grossman-Helpman word the effect of lobbying is to encourage net trade promotion. ${ }^{18}$ Hence, the Grossman-Helpman framework not only does not help out with the puzzle, it actually makes it worse.

The starting point for any explanation for the systematic bias in favor of trade restrictions is likely to be a bit of history: revenue-hungry rulers in countries with poor administrative capabilities know that trade is an excellent tax handle. Trade taxes therefore typically contribute a very large share of government revenue in any nation's early history. In the United States, for example, tariffs provided on average more than 50 percent of 
govemment revenue from 1870 to 1914 (Baack and Ray, 1983). Prior to the Civil War, this ratio actually stood at 90 percentl (Hansen, 1990). Not surprisingly, then, the sharp drop in the average U.S. taniff rate at the start of World War I coincides with the introduction of the income tax in 1913.

Cross-country evidence is also consistent with the hypothesis that poorer countries rely more heavily on trade taxes. As shown in Table 1, there is a robust negative relationship between per capita income and the share of trade taxes in total tax revenue: an increase in per capita income of $\$ 1,000$ is associated with a reduction in 3.7 percentage points in the share of taxes that oniginate from foreign trade.

Viewed from this perspective, the political-economy puzzle becomes why the bias against trade remains even when govemments develop altemative, more efficient sources of tax revenue." That is, the puzzle about anti-trade bias tums into a puzzle about persistence. It is well known that the OECD countries have moved io non-tariff barriers just as they were reducing their reliance on import tariffs. Of course, one can appeal to the terms-of-trade benefits of trade restrictions for large countries. But this explanation would be implausible, not the least because governments have been so quick to transfer rents created by quantitative restrictions to foreign exporters through VERs. Moreover, there is corroborating historical evidence that it is difficult to take protection away once it has been given: Gardner and Kimbrough (1989) show that the average U.S. tanff follows close to a random walk in the pre1913 period (that is, any increase in the tariff was essentially permanent).

There are practically no models in the literature that deal with this issue of persistence, and very few that can account for it. ${ }^{18}$ Two exceptions are Femandez and Rodrik (1991) and Brainard and Verdier (1993). The first of these papers shows that there is a natural status. 
quo bias to policymaking whenever some of the gainers (or losers) from reform cannot be identified ex ante. Many reforms that are politically sustainable ex post will not be adopted ex ante. Femandez and Rodrik (1991) show that the bias exists even when individuals are risk neutral, rational and forward-looking.

To see how the argument works, consider a democracy where a majority vote is needed before trade reform can be adopted. Let the economy have 100 voters and suppose that the reform in question will increase the incomes of 51 individuals by $\$ 5$ each and decrease the incomes of the rest by $\$ 1$ each, leaving a net gain of $(5 \times 51)-(1 \times 49)=\$ 206$. In the absence of uncertainty, the majority of the population would vote in favor and the reform would be adopted. We assume that all these consequences of reform are common knowledge. Now suppose that while 49 individuals know for sure that they will gain, the remaining 51 are in the dark as to which among them will gain and which will lose; however, since aggregate consequences are common knowledge, individuals in the latter group know that two of them will eventually benefit while $\mathbf{4 9}$ will lose out. (Such uncertainty may arise from, say, incomplete information at the individual level about the skills needed to succeed in the post-reform environment.) This renders individuals in the second group identical ex ante, with an expected benefit from reform of $[(5 \times 2)-(1 \times 49) y 51=-\$ 0.76$ each. Hence the individuals in the uncertain group will reject reform, blocking its adoption.

Conversely, uncertainty of this kind can lead to reforms that will prove unpopular ex post (and hence be reversed) to be adopted ex ante. The bias towards the status quo derives from the following asymmetry: due to the uncertainty about the consequences of the reform, some reforms that will be ex post unsustainable are adopted, while some that would have been sustalnable are not. Both of these types of "error" leave the polity in the statusquo position (as the former cases are eventually followed by a retum to the status quo). 
Brainard and Verdier (1993) use a dynamic version of the Grossman-Helpman (1992) framework to show that industries that have high protection today are more likely to have high protection tomorrow as well. The reason is that current protection makes these industries adjust (contract) less, with the result that output will be higher in the future than in the absence of the protection. The higher future output in tum translates in the GrossmanHelpman framework into greater future protection.

To sum up, to date very little attention has been paid to explaining why trade policies are systematically biased against trade. What I have argued here is that a two-part explanation for this bias holds the greatest promise. First, the initial conditions: since trade is a convenient tax handle, most govemments inherit trade taxes originally put in place for (evenue motives. Second, persistence and status-qijo bias: once protection is awarded, it is difficult to take it away. However, more work is needed on this last point.

\section{Protection Across Industries, Countries, and Time}

What are the determinants of protection levels across different industries, among countries, or over time? These questions, and particularty the first one, have been the subject of a large body of empinical literature. The typical approach in the empirical work has been to regress some measure of protection on a number of economic and political variables. ${ }^{19}$ While the relevance of the included independent variables is typically motivated by appealing loosely to the theoretical literature, the links between the empirical and theoretical work have never been too strong in this area. Regression analysis often takes the kitchen-sink approach, with a large number of "relevant" variables-some obviously endogenous-thrown in on the righthand side. None of the leading approaches discussed earlier has been subjected to direct empirical test. On the other hand, nor are some of the empirical regularities uncovered by the 
econometric work adequately explained by existing theory (see below).

There exist quite a few surveys of the empirical literature on the political economy of trade policy (Ray, 1990; Marks and McArthur, 1990; Anderson and Baldwin, 1987). Therefore, I will only summarize some of the main conclusions coming out of this literature and relate these to theory.

6.1 Protection across industries. The cross-industry determinants of levels of protection within a country have been analyzed in a regression framework by a large number of authors. The studies to date have focussed on advanced industrial countries (mainly the U.S.), and have used many different indicators of trade protection, including nominal and effective tariffs, nontariff coverage ratios, and exemptions from multilateral trade liberalization. To summarize the key findings of this literature, the protection received by an industry is higher when:

- it is a labor-intensive, low-skill, low-wage industry (Caves, 1976; Saunders, 1980; Anderson, 1980; Ray 1981; Marvel and Ray, 1983; Baldwin 1985; Anderson and Baldwin, 1987; Ray 1991; Finger and Harrison, 1994);

- it has high import penetration (Anderson, 1980; Finger and Harrison, 1994), has experienced an increase in import penetration (Trefler, 1993), or has been in decline (Marvel and Ray, 1983; Ray 1991):

- it produces consumer goods rather than intermediate goods (Baack and Ray, 1983; Marvel and Ray 1983; Ray 1991);

- its production is regionally concentrated (Pincus, 1975; Caves, 1976; Godek. 1985), except for in the case of non-tariff bamiers (Ray, 1981);

- it engages in little intra-industry trade (Ray, 1991; Marvel and Ray, 1987);

- its customers are not highly concentrated (Pincus, 1975; Trefler, 1993). 
High leveis of concentration in the affected industry itself is apparently not always conducive to protection: some studies find a negative relationship between seller concentration and protection Anderson and Baldwin, 1987; Finger, Hall, and Nelson, 1982), while many others find a positive relationship (Pincus, 1975; Saunders, 1980; Marvel and Ray, 1983; Godek. 1985; Trefler, 1993). Another noteworthy finding is that tariffs and non-tariff barriers are complements (Ray, 1981; Ray and Marvel, 1984; Godek, 1985). We note that the studies listed here are not directly comparable for a number of reasons: they use different measures of protection, cover different countries and time periods, and include different sets of righthand side variables.

One recent paper in this tradition that is particularty noteworthy is Trefler (1993). This paper is novel in that it considers the joint determination of import penetration levels with nontariff protection. The argument is that there is a two-way dependence between these two: an increase in import penetration stimulates demands for NTBs, while an increase in NTBs naturally restrict imports. The correct procedure, therefore, is to undertake a simultaneous estimation of the import-penetration and NTB equations. Once the endogeneity of NTBs is taken into account, Treffer shows that the restrictive effect of NTBs on U.S. trade is much greater than what is usually estimated in single-equation trade models. He finds that the 1983 average import penetration in U.S. manufactures would rise from 13.8 to 15.4 percent, which is equivalent to an increase in actual imports of $\$ 49.5$ billion under conservative estimates With regard to the NTB equation. Trefler finds that the level of NTB coverage is positively and significantly correlated not with the level of import penetration but with the change in it.

These empirical regularities overtap only imperfectly with the results of the theoretical literature. The finding that advanced industrial countries protect mainly their labor-intensive sectors is essentially a consequence of the fact these are their import-competing sectors. As 
discussed above, the theoretical fiterature does not provide any robust reason as to why protection should be biased in favor of sectors with comparative disadvantage.

The finding with respect to import-penetration levels (or the changes therein) is also poorty explained. The Grossman-Helpman model in fact yields the opposite presumption, namely that sectors with high import penetration should get low protection. ${ }^{20.21}$ Hillman (1982) and van Long and Vousden (1991) use the politicat-support function approach to explain why declining industries get more protection: when the wortd price of an import-competing sector drops, the policymaker wants the rest of society to share the cost, so she raises the tariff. Note that the logic in this story is not essentially political, but has to do with risk-sharing. The same outcome obtains in Staiger and Tabellini (1987) as well, where the govemment does not have an explicitly political motive, and simply wants to redistribute income from groups with Low marginal utility of income at the margin--those adversely affected by trade-to those with high marginal utility. ${ }^{2 n}$

Regarding the nature of the industry's output (consumer versus intermediate good) and its market structure, there is again a dearth of theoretical research. It is of course reasonable that intermediate-good industries will have a comparatively hard time receiving protection, as long as consumer interests are less well organized and represented than producer interests. But almost all theoretical models of political economy exclude intermediate goods and focus on consumer goods (see however last section of Grossman and Helpman, 1992). On industry structure, it is perhaps disappointing that the empirical literature is not more clearcut on the political advantages of high concentration, in view of the strong presumption that free-rider effects should be important in lobbying. Here too, however, theoretical contributions are scant. In Rodrik (1987), there is an unambiguous negative relationship between the numbers of firm in an industry and the amount of tariff protection it receives. Hillman (1991) has 
undertaken a more complete analysis using a model where owner-managers have to choose how much to invest in internal monitoring of their production activity and how much to lobby in favor of a tariff. He finds that the relationship between concentration and the level of protection is ambiguous in general. ${ }^{3}$

Finally, on intra-industry trade, it stands to reason that pressures for protection are diluted in industries where two-way trade is significant. Krugman's original work on intemational trade with monopolistic competition was motivated at least in part by the observation that the huge expansion of intra-OECD trade in the postwar period has apparently taken place without large distributive effects, and hence with few political-economy repercussions (Krugman, 1981). And one interpretation of the disproportionate barriers facing Japanese exports in importing countries is that these are the consequence of Japan's much lower share of intra-industry trade relative to other developed countries. ${ }^{24}$ Interestingly, the relationship between intra-industry trade and the political economy of trade policy has not been formally modelled. The only exception seems to be a paper by Levy (1993b), who does so in the context of the debate between bilateralism and multilateralism. Levy models a world with both intra-industry trade and Heckscher-Ohlin trade. An expansion of the former benefits everyone, while an expansion of the latter has redistributive effects along Stolper-Samuelson lines. He shows that the option of integrating with a similar economy ("bilateralism") may foreclose the option of multilateral free trade, when the median voter stands to lose from Heckscher-Ohlin trade.

\subsection{Protection across countries or institutional contexts. There is great variation among} countries in their average leveis of protection. Developing countries, in particular, have much higher levels of protection than the advanced industrial countries-although recently this has 
begun to change in the case of Latin American countries. Among the industrial countries, the small European countries have tended to be more open (at least when agriculture is excluded) than the larger economies. The empinical literature on the determinants of cross-country protection is not large. In fact, I found only few systematic studies on the subject.

Magee et al. (1989, chap. 16) find that average tariff rates tend to decrease across countries as capitallabor ratios increase. This is a reflection of the fact that rich countries have lower protection than poor countries. As noted above, there is a solid revenue reason for why this should be so, independent of political ecrnomy. In addition, developing countries have been until recently under the influence of infant-industry reasoning. Once these motives are controlled for, it is unclear whether political circumstances provide additional explanatory power for the observed tendency of poor countries to be more protectionist.

Anderson (1993) has analyzed a related asymmetry conceming rich and poor countries: poor countries tend to tax agriculture while rich countries subsidize it. Anderson's main argument is that a tax on agriculture in a developing country results in a relatively small cost for farmers but a big gain for industrialists, while an agricultural subsidy in a developed country entails big gains for farmers but small costs to industrialists. This asymmetry is the consequence of a number of structural differences: in a developing country, agricultural production is a larger share of GDP, uses less capital and industrial inputs, and is a bigger part of domestic consumption. Anderson uses a CGE model with parameters reflecting archetypal developing and developed countries to demonstrate the asymmetric distributional implications of taxing/subsidizing agriculture.

The cross-national variation in average protection levels among advanced industrial countries is examined in Mansfield and Busch (1993). Their sample is smalt-14 countries pooled over two years, 1983 and 1986-but the results are interesting. They find that non-tanif 
barriers are higher in countries that are larger in size (in terms of either GDP or imports), have higher unemployment rates, have larger number of parliamentary constituencies, and use proportional representation (PR) as their electoral system.

The last two findings deserve special comment, as they are concrete indication that the institutional context of government matters. Following Rogowski (1987), Mansfield and Busch argue that the number of constituencies is an inverse measure of the "insulation" of the executive from narrow interest groups. The reason is that the smaller the average size of the constituency the more likely that a single group can exercise political power. When automakers or dairy farmers entirely dominate twenty small constituencies and are a powerful minority in fifty more, their voice will certainly be heard in the nation's councils" (Rogowski. 1987, 208). This expectation is bome out in the results. The presence of a PR system in tum is taken to indicate that the executive possesses greater "autonomy" as list-system PR tends to lead to strong parties: "[o]ressure groups are restrained where campaign resources or the legal control of nominations are centralized in the hands of party leaders" (Rogowski, 1987. 209). The Mansfield-Busch finding that PR systems are associated with higher NTBs, however, contradicts this line of reasoning.

Theoretical and empirical work relating institutional contexts to trade policy outcomes is in its infancy but should be a promising area of research. Cross-national studies necessarily confront variability in institutional context. Single-country studies do not necessarily do so, although different trade policy "tracks" exhibiting different institutional realities may well coexist within a single political entity. Finger, Hall, and Nelson (1982), in particular, have made this argument for the United States. They distinguish between a "technical" track and a "political" track en route to protection. In the case of anti-dumping proceedings, for example, the determination of whether there has been dumping is a largely technical one, whereas the 
determination of injury is more political. The rules for the former determination are mole clearty specified, while the rules for the latter are more subjective and open to interpretation. Consistent with this hypothesis, Finger at al. find that in less-than-fair value (LFV) pricing determinations, political factors such as industry concentration and size of industry either do not play a role or enter with the "wrong" sign (concentration), while technical factors play an important role. In the case of injury determinations, size of employment enters positively and significantly, while technical factors play a much smaller role. Hence, just as in the RogowskiMansfield-Busch line of analysis, different rules of the game produce different outcomes. ${ }^{25}$

\subsection{Protection over time. Some of the trends in trade policy over time have already been} noted. Notably, countries have tended to reduce their levels of trade restrictions, and, at least among developed countries, there has been a shift away from tariffs in the direction of nontariff bamiers. The former is probably best explained by the development of altemative tax instruments as countries develop, and by the falling out of favor of import-substitution and infant-industry arguments. As for the shift towards NTBs, this is usually explained by reference to successive rounds of agreements under the GATT, which by cutting and binding tariffs have left govemments little discretion over their tariff levels. So govemments that want to protect have little choice but to resort to NTBs. Note that this argument, as stated, is incomplete. That multiateral agreements under GATT restrict freedom of action for tariffs but not for all kinds of NTBs is common knowledge to all parties concemed. Why governments still have the incentive to negotiate agreements that they know they and others will be fille to flout by resorting to NTBs is not so easily explained.

In this sub-section I focus on the following two questions: (i) what do we know about the determinants of short-term fluctuations in levels of trade protection? (ii) what explains the 
drastic reversals in trade policy we occasionally observe?

With regard to the time-series correlates of protection, there exists a number of studies for the United States. That the average tariff level tends to rise in recessions is a robust finding in this literature (Ray, 1987; Hansen, 1990; O'Halloran, 1993). In the most careful empirical study to date of the historical experience of the U.S. with tariffs, Bohara and Kaempfer (1991) find that U.S. tarifts are Granger-caused by unemployment, real GNP, the price level, but not the trade balance. Presumably the reason tariffs tend to increase in recessions is the Keynesian motive of switching demand to home products. Note, however, that the practice predates Keynes. ${ }^{20}$ In addition, historically Republicans have tended to raise tariffs while Democrats have reduced them (O'Halloran, 1993; Magee, Brock, and Young. 1989, chap. 13). ${ }^{27}$ O'Halloran (1993) emphasizes the importance of political parties taking distinct positions on the tariff issue and implementing them when elected. She takes this to indicate that parties are more than pure sggregators of social pressures, thus reflecting the importance of political institutions.

One interesting time-series study outside the U.S. context is Rama's (1993) work on Unguay. In this study, Rama goes through historical govemment records to count the annual number of statutes relating to foreign trade over the 1925-1983 period. He distinguishes between regulations imposed to the benefit of a single firm or industry and regulations that seem more broadly public-spirited, with the first presumably indicating rent-seeking activities. These series are then scaled by aggregate output or exports. Rama regresses this measure of rent-seeking on its lagged value and a series of dummies that represent sub-periods with different political and trade-policy regimes. He finds that sub-periods with policy activismeither in the direction of Import substitution or export promotion-are also ones in which rentseeking activity is largest. This is a notable paper in it at it is one of the few attempts to 
seriously quantify rent-seeking in the trade policy arena, and to delineate its relationship to the government's policy stance.

Finally, let us tum to cases of sharp reversal in trade policy. Such cases pose problems of explanation because the distributional consequences of trade-the basis for trade politics-are unlikely to change very rapidly. Cassing and Hillman (1986) provide a model in which small changes in extemal conditions can have drastic effects on trade policy: the reason is that declines in economic and political standing are related and can amplity each other's effects. Other explanations are related to changes in the institutional background. A significant instance is provided by the experience of the United States since the passage of the Reciprocal Trade Act of 1934. Following this act, which delegated Congressional authority over tariff-setting to the President, U.S. tariff levels declined significantly. It has been suggested that this particular institutional innovation-delegation-was chiefly responsible for the subsequent move towards free trade, as the President is presumed to be less susceptible to pressure from narrow pressure groups (Pincus, 1986; Baldwin, 1991).

O'Halloran (1993) has provided a more nuanced argument about the role of delegation, in which "Congress meticulously designs procedures to ensure that the actions taken by the president are in line with legislators' preferences" $(1993,5-6)$. In this view, delegation to the executive is a willful action aimed at getting desirable outcomes. O'Halloran shows that Congress delegates less authority to the president of an opposing party, with the consequence that divided govemment is associated with higher levels of protection. Once again, these considerations highlight the role played by the institutional setting in determining trade policy outcomes.

More recently, a growing number of developing countries have accomplished a dramatic tum-around by abandoning their protectionist trade regimes in favor of more open 
trade policies (Bolivia and Mexico since 1985, Argentina since 1987, Brazil since 1988, Peru since 1990). What makes this change in course difficult to explain is that it has taken place in the most unfavorable economic circumstances: these countries were all mired in deep macroeconomic crises with high inflation and stagnant or falling output at the time that they decided to open up. A small literature has emerged trying to explain the puzzle. Many of the explanations center on the political benefits of a deep economic crisis in enabling policy reform. Drazen and Grilli (1993) focus on a "war of attrition" between two social groups and show that a negative shock (a "crisis") leads to an earlier resolution of the conflict. In Rodrik (1994), I explain the reforms by arguing that a deep economic crisis relegates distributional considerations to second place behind economy-wide concems, and therefore allows an agenda-selting govemment to sneak in trade policy reforms alongside macroeconomic reforms.

\section{Consequences of Viewing Trade Policy from PolticalEconomy Lenses}

This paper has so far focussed on the contribution that the political-economy perspective can make to our understanding of the actual conduct of trade policy. But there is an additional payoff. Politicaleconomy models can actually enhance the sophistication of our economic analysis as well, by providing a fuller account of the likely consequences of policy. In addition, they can be an imporlant input to the design of appropriate institutions and regimes in the trade policy area. Consequently, they can be invaluable for normative analysis as well as positive analysis (Rodrik, 1993). I conclude this essay by giving some illustrations. Trefler's (1993) empinical analysis of non-taritt bariers in the U.S., discussed earlier. provides an excellent example of how political-econoriy analysis enriches our understanding of the economic consequences of trade policy. Trefler notes that the level of imports and of 
NTBs are both endogenous and influence each othei. A single-equation framework that regressed import quantities on NTBs would be subject to simultaneous-equation bias, as import penetration has consequences in tum for NTB levels thanks to political forces. in fact, he finds that the simultaneous-equation estimate of the restrictiveness of NTBs on U.S. imports is 10 times larger than the single-equation estimate. Hence, viewing NTBs as endogenous rather than exogenous corrects the previous literature's conclusion that the effect of trade restrictions on import quantities has been small. ${ }^{20,29}$

As an additional example, consider the paper by Brainard and Verdier (1993). As this paper shows, taking into account the endogeneity of protection gives us a more complete understanding of the process of inter-sectoral resource flows. The easier it is for industries to obtain protection in response to a fall in their price, the slower is the rate of adjustment, and the higher is the long run capacity in the sector experiencing the adverse shock. So, the "specificity" of factors to an industry becomes endogenous through the political process. Our economic models would not give a full account short of taking this endogeneity into account.

One can go one step further. Economic behavior is distorted not onty by the actual imposition of trade restrictions, but by the prospect of their imposition as well-even if the prospect never becomes reality. So, even Trefler's estimates are biased downwards to the extent that foreign exporters are reducing their sales in the U.S. market to moderate the likelihood that they will bring protection on themselves. Leidy (1993) provides a useful broad discussion of this issue. As he puts it,

[t]he prospect of protection, as it is institutionalized in the policy formation process and the rules for administered protection, can induce real changes in economic activity independent of whether actual barriers have been imposed. Import-competing and exporting firms may be able to manage the prospect of protection under existing rules by modifying decisions pertaining to foreign direct investment, output, employment. exports, capital expenditures, and the like.... The mere absence of current barriers to trade in some sectors, therefore, is not sufficient to assume, as is typically done in pure trade theory, that firm conduct and trade is free of policy-induced distortions" 
(Leidy, 1993, 2).

Bhagwati and Srinivasan's (1976) work on endogenous "market disruption" is the first paper that formalized this idea in a particular instance: if the exporting industry does not internalize the risk of protection in the importing country, it is desirable to impose an export tax on it. Leidy (1993) reviews other papers in this tradition. Winters (1994) provides evidence that the European Union's practice of "import surveillance" (the collection of detailed statistics on particular imports either prior to or immediately after their importation) can lead to reduced imports.

A consistent theme in the political-economy literature is that trade policies can have unanticipated effects unless their political consequences are taken into account. Krueger's (1974) paper on rent-seeking is of course the foremost source on this. A recent application is Sturzenegger (1993), which shows that the rent-shifting benefits of strategic trade policy can be undone completely if the policy leads to rent-seeking that competes with R\&D activity for resources. Largely in view of such considerations, Krugman (1993) has argued that free trade remains a good rule of thumb, even if not the optimal policy in an imperfectly-competitive wortd. However, more work remains to be done on this-to demonstrate in particular the circumstances under which free trade is a politically sustainable policy.

All these considerations suggest that it is important to have a good idea of political economy consequences when advocating policies or designing institutions. The literature on this is not very large. Aside from the papers mentioried above, we can cite Richardson (1993), Riezman and Wilson (1993b), and Panagariya and Rodrik (1993). Richardson (1993) focusses on the differing implications of a customs union and a free trade area for trade diversion in a model where tariff levels are determined endogenously: he shows that an FTA has the added benefit that tariff levels are likely to decline endogenously. Riezman and 
Wilson (1993b) discuss the consequences for taniff le:els of various kinds of political reforms such as ceilings on political contributions, and argue that these restrictions can be easily offset by behavioral adjustments on the part of politicians and lobbyists. Panagariya and Rodrik (1993) consider whether a uniform taniff rule may be desirable as a way of diminishing sectoral pressure for protection.

One important advantage of this line of research is to place on a more solid analytical footing the loose and informal political-economy arguments often deployed in favor of one policy regime or another. As pointed out in Rodrik (1993), the political arguments in favor of, say, uniformity in tariff schedules or shock therapy in trade reform do not have to rest on hand-waving. It is necessary to construct nigorous models to demonstrate the logical soundness of such propositions, no matter how intuitive they may seem.

An analogy with macroeconomic policy is useful here. Thanks in part to the research on time consistency, much of the literature on fiscal and monetary policy has long focussed on the design of rule-based regimes and institutions which would enhance price stability without damaging real activity. Think of the work on central-bank independence or optimum currency zones, for example. In trade policy, we have an analogous set of questions. In particular, we would like to know what kind of multilateral, bilateral, or unilateral rules ("regimes") are: (a) politically feasible, and (b) most conducive to the emergence of desirable trade policies. What is the best way to structure interest-group participation in the policy-making process? Do constitutional restrictions on certain types of trade policies (export taxes? VERs?) make sense? When is delegation of trade policy to the exe:u'jve feasible, and does it always help in reducing protection? Should trade policy be camied out in a centralized or de-centralized manner? Are regional arrangements desirable as a complement (or substitute) to multilateral institutions? What kind of "safeguard" measures should a multilateral regime sanction to 
sustain relatively free trade? All these questions are political in nature, and it is natural to tum to the political economy literature for assistance. So far, there has been little work on such issues, but my guess is that this is an area very well worth exploring. ${ }^{30}$

\section{Concluding remarks}

Economists have ahways been aware that the determinants of trade policy are deep down political. There is a long and distinguished literature that attests to this awareness. However, I have indicated here a number of areas where more progress is needed. First, we do not fully understand the apparent political advantage of trade policy in redistributing income over more direct policy instruments. Second, we lack a good explanation of the universal preference for trade-restricting policies over trade-promoting ones. Third, the theoretical and empirical literatures dealing with the determinants of protection levels across industries, countries, and time need to be better integrated. Finally, there is plenty of room for sketching out the implications of hard-headed political-economy analysis for normative economics. 


\section{References}

Anderson, K. (1980) "The political market for govemment assistance to Australian manufacturing industries," The Economic Record 56 (153), June, 132-44.

Anderson, K. (1993) "Lobbying incentives and the pattem of protection in rich and poor countries," Economic Develogment and Cultural Change 41.

Anderson, K., and R.E. Baldwin (1987) The political market for protection in industrial countries," in A.M. Er-Agraa, ed., Protection. cooperation, integration and development. Now York: Macmillan.

Austen-Smith, D. (1991) "Rational consumers and irrational voters," Economics \& Politics 3(1), March, 73-92.

Baack, B.D. and E.J. Ray (1983) The political economy of tariff policy: A case study of the United States," Explorations in Economic History 20, 73-93.

Baldwin, R.E. (1969) "The case against infant-industry promotion," Joumal of Political Economy 77, 295-305.

Baidwin, R.E. (1976) "The political economy of postwar U.S. trade policy," The Bulletin (Now York University Graduate School of Business Administration), no. 4.

Baldwin, R.E. (1989) "The political economy of free trade," Joumal of Economic Perspectives 3(4), Fall, 119-135.

Baldwin, R.E. (1991) "The political-economy perspective on trade policy," in A. Hillman, ed., Markets and politicians: Politicized economic choice. Boston: Kluwer Academic Publishers.

Becker, G. (1983) "A theory of competition among pressure groups for political influence," Quarterty Joumal of Economics XCVIII(3), August, 371-400.

Becker, G. (1985) "Public policies, pressure groups and deadweight costs," Joumal of Public Economics 28, 329-347.

Bergsten, C.F. and M. Noland (1993) Reconcilable differences? United-States-Japan economic conflict. Washington, DC: Institute for Intrenational Economics.

Bemheim, B.D. and M.D. Whinston (1986) "Menu auctions, resource allocation, and economic influence," Quarterly Joumal of Economics 101, February, 1-31.

Bhagwati, J.N. and T.N. Srinivasan (1976) "Optimal trade policy and compensation under endogenous uncertainty," Joumal of Intemational Economics 6, 317-336.

Bohara, A.K. and W.H. Kaempfer (1991) "A test of tariff endogeneity in the United States," American Economic Review 81(4), September, 952-960. 
Brainard, S.L. and T. Verdier (1993) "The political economy of declining industries: Senescent industry collapse revisited," National Bureau of Economic Research Working Paper No. 4606, December.

Bronars, S.G., and J.R. Lott, Jr. (1994) "Do campaign donations alter how politicians vote?" unpublished manuscript, University of Pennsylvania.

Cassing, J., and A. Hillman (1986) "Shifting comparative advantage and senescent industry collapse," American Economic Review 76, 516-523.

Cassing, J., T.J. MCKeown, and J. Ochs (1986) "The political economy of the tariff cycle," American Political Science Review 80(3), September, 843-862.

Caves, R.E. (1976) "Economic models of political choice: Canadä's tariff structure," Canadian Joumal of Economics 9, 278-300.

Coate S., and S. Morris (1993) "On the form of transfers to special interests," unpublished paper, University of Pennsylvania, July.

Corden, W.M. (1974) Trade poticy and economic welfare. Oxford: Oxford University Press.

Destler, I.M., and J. Odell (1987) Anti-protection: Changing forces in United States trade politics. Washington, D.C.: Institute for International Economics.

Devereux, J. and L.L. Chen (1993) "The external terms of trade, growth and endogenous trade liberalization," unpublished paper, December.

Dixit, A.K. (1985) "Tax policy in open economies," in: A.J. Auerbach and M. Feldstein, eds., Handbook of public economics, vol. I. Amsterdam: North-Holland.

Drazen, A. and V. Grilli (1993) "The benefit of crises for economic reforms," American Economic Review 83(3), June, 598-607.

Feenstra, R.C., and J.N. Bhagwati (1982) "Taniff seeking and the efficient taniff," in: J.N. Bhagwati, ed., Import competition and response. Chicago and London: The University of Chicago Press.

Feenstra, R.C. and T.R. Lewis (1991E) "Distributing the gains from trade with incomplete information," Economics \& Politics 3(1), March, 21-40.

Feenstra, R.C. and T.R. Lewis (1991b) "Negotiated trade restrictions with political pressure," Quarterty Joumal of Economics, Noveriber, 1287-1307.

Femandez, R. and D. Rodrik (1991) "Rutsistance to reform: Status-quo bias in the presence of individuat-specific uncertainty," America) Economic Review 81(5), December, 1146-1155.

Finger, J.M., H.K. Hall, and D. Nelson ( 982), "The political economy of administered protection," American Economic Review 72(3), June, 452-466. 
Finger, M. and A. Hamson (1994) "The MFA paradox: More protection and more trade?" unpublished paper, The World Bank, February.

Gardner, G.W. and K.P. Kimbrough (1989) "The behavior of U.S. tariff rates," American Economic Review 79(1), March, 211-218.

Godek, P.E. (1985) "Industry structure and redistribution through trade restrictions," The Joumal of Law and Economics XXVIII, October, 687-703.

Grossman, G.M., and E. Helpman (1992) "Protection for sale," Princeton University, August.

Grossman, G.M., and E. Helpman (1993a) "Trade wars and trade talks," National Bureau of Economic Research Working Paper No. 4280, February.

Grossman, G.M., and E. Helpman (1993b) The politics of free trade agreements," National Bureau of Economic Research Working Paper No. 4597, December.

Hall, H.K., and D. Nelson (1992) "Institutional structure in the political economy of protection: Legislated v. administered protection," Economics \& Politics 4(1), March, 61-77.

Hansen, J.M. (1990) "Taxation and the political economy of the tariff," Intemational Organization 44(4), Autumn, 527-552.

Helpman, E., and P. Krugman Market structure and foreign trade. Cambridge, MA: The MIT Pess.

Hillman, A.L. (1989) The political economy of protection. Chur. Harwood Academic Publishers.

Hillman, A.L. (1990) "Protectionist policy as the regulation of intemational industry," Public Choice 67, 101-110.

Hillman, A.L. (1991) "Protection, politics and market structure," in: E. Helpman and A. Razin, eds., Intemational trade and trade policy. Cambridge, MA: MIT Press.

Hillman A.L., and P. Moser (1995) "Trade liberalization as politically optimal exchange of market access," in: M. Canzoneri, W. Ethier, and V. Grilli, eds., The new transatlantic economy. London and New York : Cambridge University Press.

Hitlman A.L., and H.W. Ursprung (198E) "Domestic politics, foreign interests, and intemational trade policy," American Economic Review 78(4), September, $729-745$.

Irwin, D.A. (1994) "Trade politics and the semiconductor industry," National Bureau of Economic Research Working Paper No. 4745, May.

Kahneman, D. and A. Tversky (1979) "Prospect theory: An analysis of decision under risk," Econometrica 47, March, 263-291. 
Kahneman, D. and A. Tversky (1984) "Choices, values, and frames," American Psychologist 4, April, 341-350.

Krueger, A.O. (1974) "The political economy of the rent-seeking society," American Economic Review 64, 291-303.

Krugman, P. (1981) "Intraindustry sepcialization and the gains fom trade," Joumal of Political Economy 89, 959-973.

Krugman. P. (1993) "The narrow and broad arguments for free trade," American Economic Review 83(2), May, 362-366.

Leidy, M.P. (1993) "Trade policy and indirect rent seeking: A synthesis of recent work," University of Michigan, unpublished paper, May.

Levy. P.I. (1993a) "Lobbying and intemational cooperation in tariff selting," unpublished paper, Stanford University, November.

Levy, P.I. (1993b) "A political-economic analysis of free trade agreements," unpublished paper, Stanford University, January.

Magee, S.P. (1994) "Endogenous protection: A survey," in: D.C. Mueller, ed., Handbook of public choice. Cambridge, MA: Basil Blackwell.

Magee, S.P., W.A. Brock, and L. Young (1989) Black hole tariffs and endogenous policy theory. Cambridge and New York: Cambridge University Press.

Magleby, D.B., and C.J. Nelson (1990) The money chase: Congressional campaign finance reform. Washington, D.C.: The Brookings Institution.

Mansfield, E.D. and M.L. Busch (1993) "The political economy of non-tarift barriersL A crossnational analysis," unpublished manuscript, Columbia University, October.

Marks, S.V., and J. McArthur (1990) "Empirical analyses of the determinants of protection: A survey and some new results." In: J.S. Odell and T.D. Willett (eds.), Intemational trade policies: Gains from exchange between economics and political science. Ann Arbor. The University of Michigan Press.

Marvel., H.P. and E.J. Ray (1983) The Kennedy Round: Evidence on the regulation of trade in the U.S.," American Economic Review 73(3), March, 190-197.

Marvel, H.P. and E.J. Ray (1987) "Intra-industry trade: Sources and effects on protection," Joumal of Political Economy 95(6), December, 1278-1291.

Mayer, W. (1984) "Endogenous tariff formation." American Economic Review 74(5),

December, 970-985.

Mayer, W. (1991) "The political economy of trade policy formulation," unpublished paper, 
June.

Mayer, W. and J. Li (1994) "Interest groups, electoral competition, and probabilistic voling for trade policies," Economics \& Politics 6(1), March, 59-77.

Mayer, W. and R. Riezman (1987) "Endogenous choice of trade policy instruments," Joumal of Intemational Economics 23, 377-381.

Mayer, W. and R. Riezman (1989) "Taniff formation in a multidimensional voting model," Economics \& Politics 1(1), Spring, 61-79.

Mayer, W. and R. Riezman (1990) "Voler preferences for trade policy instruments," Economics \& Politics 2(3). November, 259-273.

Milner, H.V. (1988) Resisting protectionism: Global industries and the politics of intemational trade. Princeton, N.J.: Princeton University Press.

Moore, M.O. (1994) "Steel protection in the 1980s: The waning influence of big steel?" National Bureau of Economic Research Working Paper No. 4760, June.

Nelson, D. (1988) "Endogenous taniff theory: A critical survey." American Joumal of Political Science 32(3), 796-837.

Nelson, D. (1994) "The political economy of U.S. automobile protection," National Bureau of Economic Research Working Paper No. 4746, May.

O'Halloran, S. (1993) Politics, process, and American trade policy, book manuscript (forthcoming, University of Michigan Press).

Orden, D. (1994) "Agricultural interest groups and the North American Free Trade Agreement," National Bureau of Economic Research Working Paper No. 4790, July.

Panaganya, A. and D. Rodrik (1993) "Political economy arguments for a uniform tariff," Intemational Economic Review, August.

Pincus, J.J. (1975) "Pressure groups and the pattem of tariffs," Joumal of Political Economy $83,757-778$.

Pincus, J.J. (1986) "Why have U.S. taniffs fallen since 1930," in: R.H. Snape, ed., Issues in world trade policy. New York: St. Martin's Press.

Rama, M. (1993) "Endogenous trade policy: A time-series approach," unpublished paper, The World Bank.

Ray, E.J. (1981). "The determinants of taniff and non-taniff trade restrictions in the United States," Joumal of Political Economy 89, 105-121.

Ray, E.J. (1987) "Changing pattems of protectionism: The fall in tarifs and the rise in non- 
taniff bamiers," Northwestem Joumal of Intemational Law \& Business 8(2), Fall, 285-327.

Ray, E.J. (1990) "Empirical research on the political economy of trade," in: C.A. Carter, A.F. McCalla, and J. Sharples, eds., Imperfect competition and political economy. Boulder.

Vestview Press.

Ray, E.J., (1991) "Protection of manufactures in the United States," in: D. Greenaway, ed., Global protectionism: Is the U.S. playing on a level field? London: Macmillan.

Ray, E.J. and H.P. Marvel (1984) "The pattem of protection in the industrialized world," Review of Economics and Statistics LXVI(3), August, 452-58.

Richardson, M. (1993) "Endogenous protection and trade diversion," Joumal of Intemational Economics 34(3/4), May, 309-324.

Riezman, R., and J.D. Wilson (1993a) "Politics and trade policy," unpublished paper, The University of lowa, April.

Riezman, R., and J.D. Wilson (1993b) "Political eform and trade policy," unpublished paper, The University of lowa, March.

Rodrik, D. (1986) "Tariffs, subsidies, and welfare with endogenous policy," Joumal of Intemational Economics 21, 285-296.

Rodrik, D. (1987) "Policy targeting with endogenous distortion: Theory of optimum subsidy revisited," Quarterly Joumal of Economics CII(4), November, 903-910.

Rodrik, D. (1993) "The positive economics of policy reform," American Economic Review 83(2), May, 356-361.

Rodrik, D. (1994) "The rush to free trade in the developing world: Why so late? why now? will it last?" in: S. Haggard and S. Webb, eds., voting for reform: The politics of adjustment in new democracies. Now York: Oxford University Press.

Rogowski, R. (1987) "Trade and the variety of domestic institutions," Intemational Organization 41(2). Spring, 203-223.

Saunders, R.S. (1980) "The political economy of effective protection in Canada's manufacturing sector," Canadian Joumal of Economics 13, 340-348.

Staiger, R. and G. Tabellini (1987) "Discretionary trade policy and excessive protection," American Economic Review 77, 340-348.

Sturzenegger, F. (1993) "The fallacy of strategic trade policy," unpublished paper, UCLA, February.

Trefler, D. (1993) "Trade liberalization and the theory of endogenous protection," Joumal of Political Economy 101(1). 138-160. 
Van Long, N. and N. Vousden (1991) "Protectionist responses and declining industries," Joumal of Intemational Economics 30(1/2), February, 87-103.

Wilson, J.D. (1990) "Are efficiency improvements in govemment transfer polices self-defeating in equilibrium?" Economics \& Politics 2, 241-258.

Winters, L.A. (1994) "Import surveillance as a strategic trade policy," in: P. Kugman and A. Smith, eds., Empirical studies of strategic trade policy. Chicago and London: The University of Chicago Press. 
Notes

1.And one might add, as did Dick Baldwin in his comments on this paper, that this framework leaves out some important features that may need to be included: trade policies are often chosen simultaneously with other policies, so this interdependence may need to be taken into account; there is as well interdependence with foreign countries' trade policies; we need dynamic elements to understand how trade policy evolves over time; etc.

2. This formulation assumes either that imported varieties sell at the same price as domestically-produced varieties (free trade), or that no imported varieties are consumed (autarky). So, implicitly we are restricting attention to comparisons of autarky to free trade only.

3.Mayer assumes that only individuals whose real income gain from a tarift or subsidy exceeds the voting cost will choose to vote. However, this is problematic. The gain from the policy must be multiplied by the probability that the voter in question will be pivotal, which is near zero. (I am grateful to Gene Grossman for bringing this point to my attention.) This is another manifestation of the "voting paradox", a paradox which can be resolved only by assuming that voting is motivated by other than pure self interest.

4.Riezman and Wilson (1993a) call this an "inverse tariff formation function", except that its form is determined endogenously. Indeed, the determination of the form that this function will take represents the analytical core of the Grossman and Helpman paper.

5. Individuals are assumed to own at most one type of factor.

6. Whether political contributions are made to influence candidates' choices (as in GrossmanHelpman) or to increase the likelihood that a candidate of the desired ideology wins office (as in MBY) is an unsettled issue in the literature on campaign contributions. Bronars and Lott (1994) find that retining congressmen who experience large reductions in donations do not 
change how they vote in their last term, interpreting this as evidence in favor of the second hypothesis. See Magleby and Nelson (1990) for a good introduction to the literature on campaign contributions in the U.S.

7.This is the formula for a small country. In the case of a large country, there is an additional term capturing the optimum tariff motive.

8.The following critique of MBY by Austen-Smith $(1991,84)$ is equally relevant to the Grossman-Helpman model: "...lobbying activity is predominantly not financial, but rather to do with information transmission. Specifically, lobbying activity involves the efforts of individuals and groups to influence individual legislators' decisions through various forms of persuasion: for example, direct mail campaigns, face-to-face discussion about the policy consequences of a bill, providing information on the distribution of constituency support with respect to an issue, etc., etc. On the other hand, as remarked earlier, campaign contributions cannot be used legally in this way. While interest groups can give resources to support the electoral campaigns of favored candidates, they cannot do so in direct exchange for policy decisions or make donations explicitly conditional on a legislator promising to vote one way or another if elected."

9.In the preface to their book, Magee et al. Write: "the theory [developed here] describes any govemment policy motivated by special interests" (1989, xvii). This is of course precisely the problem.

10.Moreover many models of political economy contain an inconsistency: They allow tariff revenue to be distributed in lump-sum fashion back to the population. Unless the distribution is undertaken in the form of poll subsidies (an equal amount for every individual), this is inconsistent with the maintained assumption in the same papers that only tariffs can be used to redistribute income. 
11.This complication was recognized by Becker, although in passing. He notes the "tendency for the political sector to use the most efficient methods available to redistribute to beneficiaries," but then adds: "a satisfactory analysis of the choice of methods must consider whether the influence function itself depends on the methods used" $(1985,338)$.

12.Perhaps infant-industry protection fits the Coate-Morris argument best. While trade policy is rarely first- or even second-best for purposes of infant-industry promotion (Baldwin 1969), it was widely believed until recently that its use is economically justified under certain conditions. 13.In his discussion of the Trade Act of 1974, Baldwin $(1976,36)$ notes that there were few industries that testified strongly in favor of liberalization, in stark contrast to the many demands for less liberalization.

14.It could be argued that one reason for the anti-trade bias is that direct export subsidization. unlike import tariffs, has long been illegal under the GATT. However, quantitative restrictions for manufactured goods have also been GATT-illegal (save for developing countries and under proscribed conditions), yet countries have found imaginative ways of using them without sanction. Govemments have been significantly more prone to flout intemational obligations on import restrictions than on export inducements. In addition, one may ask why the prohibition on export subsidization was agreed to by govemments in the first place (when no such prohibition on import tariffs would have been feasible).

15.Sometimes appeal is made to Corden's "conservative social welfare function" to explain why there is a bias towards trade restrictions. According to this idea, "any significant absolute reductions in real incomes of any section of the community should be avoided" (Corden, 1974, 107-108). However, there is no reason to believe that over the long run export interests receive negative shocks with lower frequency (or lesser force) than do import-competing interests. And if they do not, why should there be a universal bias towards import 
restrictions?

16.Levy (1993a, p. 17) provides a good discussion of what would need to hold for anti-trade bias to exist. Judging that none of these requirements is satisfactory, he gets out of the conundrum by simply assuming that export subsidies are ruled out.

17. By the same token, explaining the bias against trade by appealing to revenue considerations-export subsidies cost money while import tariffs raise revenue-is unsatisfactory. Most advanced industrial economies have well-developed tax systems which render trade taxes unnecessary. As for developing economies, the most popular forms of protection-quantitative restrictions-do not raise revenue for the treasury. Similarty, many proexport policies (such as export targets or export performance requirements, which have been used widely in East Asia) do not require the expenditure of fiscal resources.

18. One can of course assume that the policymaker is simply loath to have any sector of the economy incur a real income loss. Corden (1974, 107) has coined the term "conservative social welfare function" to describe the objective function of a policymaker acting in this fashion.

19.In addition to econometric work, on which I will focus, there is a large body of case studies. For some recent U.S. examples, see Nelson (1994) on the auto industry, Moore (1994) on steel, Orden (1994) on agriculture in the context of NAFTA, and Imin (1994) on semiconductors.

20.As Grossman and Helpman (1992) point out in a footnote (fn. 16), however, the result can be roversed if sectors with high import penetration have very low elasticities of import demand (so that the efficiency cost of protecting them is low). Since existing empirical work does not control for sectoral differences in import demand elasticities, and add "extraneous" variables to the regressions, Grossman and Helpman argue that their theoretical results cannot be directly 
comparen with the empinical findings. This is : good illustration of the gulf that currently separates empirical and theoretical work in the area of political economy of trade policy. 21.Brainard and Verdier (1993) use the Grossman-Helpman framework to address the issue of senescent industry protection, but they simply assume that the industry starts to lobby only affer it experiences a reduction in its world price. So they cannot address the question of whether the industry receives more or less protection affer it is hit with the shock.

22.In his discussion on why declining industries get preferential treatment, Baldwin (1989) refers in passing to the work of psychologists Kahneman and Twersky $(1979,1984)$ on how individuals place greater weight on a loss than a gain of an equivalent amount.

23.An altemative approach is to consider whether an industry is able to maintain cooperative lobbying activities using trigger strategies in a dynamic setting. See Riezman and Wilson (1993a) on this.

24. Only 58 percent of Japan's trade was intra-industry in 1990, compared to 83 percent in the U.S., 73 percent in Germary, and 79 percent in Great Britain (Bergsten and Noland, 1993. 66).

25.See also Hall and Nelson (1992) on how legislative and administered protection routes may provide different incentives to lobbying industries.

26.Cassing, McKeown and Ochs (1986) provide an altemative explanation that does not depend on the Keynesian motive. They argue that "old" industries with fixed capacities benefit from increases in demand for their product disproportionately at the bottom of the business cycle.

27.As Ray (1987) points out, the Heckscher-Ohlin-Samuelson model can explain the switch in the Democrats' and Republicans' favored trade policy stances in the post-World War II period. Let the Democratic Party represent farmers and labor, and the Republican party represent 
business (capital). Prior to World War I, the U.S. was relatively poor in capital and rich in labor and land. This led the Republicans to prefer protection and Democrats to prefer free trade. As the undertying pattern of comparative advantage changes, so do party stances. By the 1970s, Democrats-representing labor-are on the anti-trade side and Republicans on the pro-trade side.

28. Treffer estimates that if U.S. manufacturing NTBs were eliminated, the average import penetration would rise from 13.8 percent to 15.4 percent, which. is an increase of $\$ 49.5$ billion under conservative assumptions.

29.In a similar vein, Devereux and Chen (1993) argue that the observed correlation between growth and openness across countries may be an artifact of the endogeneity of trade policy. As the urban industrial sector experiences growth due to technical progress, a political-support maximizing govemment will want to share the wealth by providing the rural sector some of the gains as well. The government will consequently respond to growth by reducing the protection of industry.

30. Where intemational institutions are concemed, the research that is needed would integrate the approaches discussed in this paper with those discussed by Staiger in his chapter in this volume. 


\begin{tabular}{|l|c|c|c|}
\hline \multicolumn{2}{||}{ Table 1: Relationship between Trade Taxes and Per Capita Income } \\
\hline & \multicolumn{3}{|c|}{ Dependent variable: } \\
\hline & $\begin{array}{l}\text { All trade taxes as a } \\
\text { share of total tax } \\
\text { revenue, } \\
1984-86 \text { average }\end{array}$ & $\begin{array}{l}\text { Import duties as a } \\
\text { share of total tax } \\
\text { revenue, } \\
1984-86 \text { average }\end{array}$ & $\begin{array}{l}\text { Export taxes as a } \\
\text { share of total tax } \\
\text { revenue, } \\
198486 \text { average }\end{array}$ \\
\hline Constant & $0.353^{*}$ & $0.279^{*}$ & $0.065^{\circ}$ \\
\hline $\begin{array}{l}\text { Per capita GDP } \\
(1985)\end{array}$ & $-0.037^{*}$ & $-0.030^{\circ}$ & $-0.011^{* *}$ \\
\hline$R^{2}$ & 0.18 & 0.12 & 0.07 \\
\hline number of countries & 77 & 77 & 77 \\
\hline
\end{tabular}

Source: Tax data have been supplied by the Fiscal Affairs Department, IMF. Per capita GDP is from the Heston-Summers data set.

Notes: - significant at the $1 \%$ level;

$\rightarrow$ significant at the $5 \%$ level. 

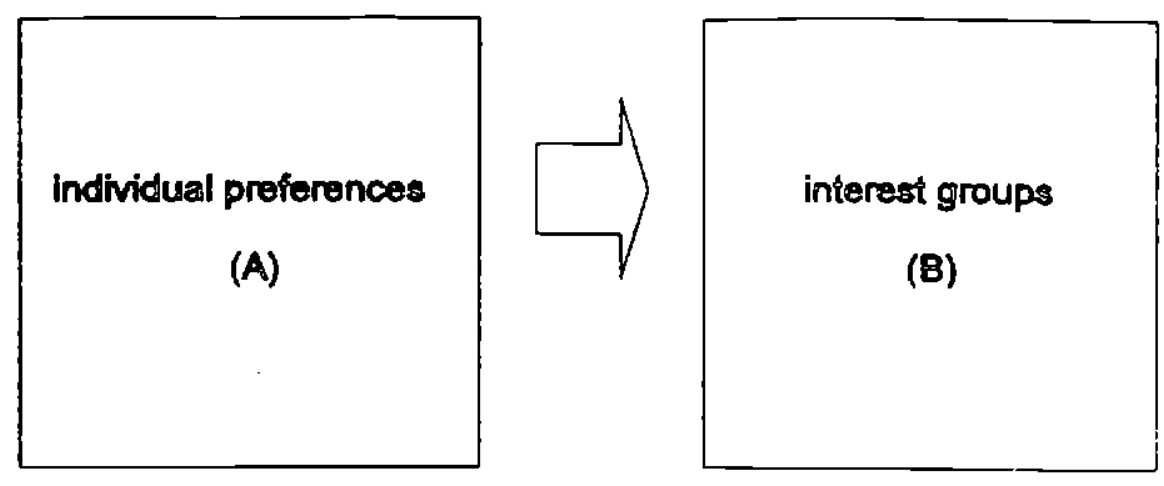

"demand side"
of trade policy

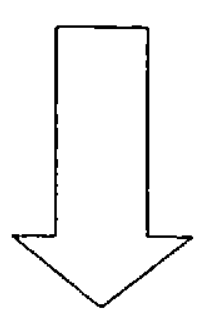

trade policy outcomes
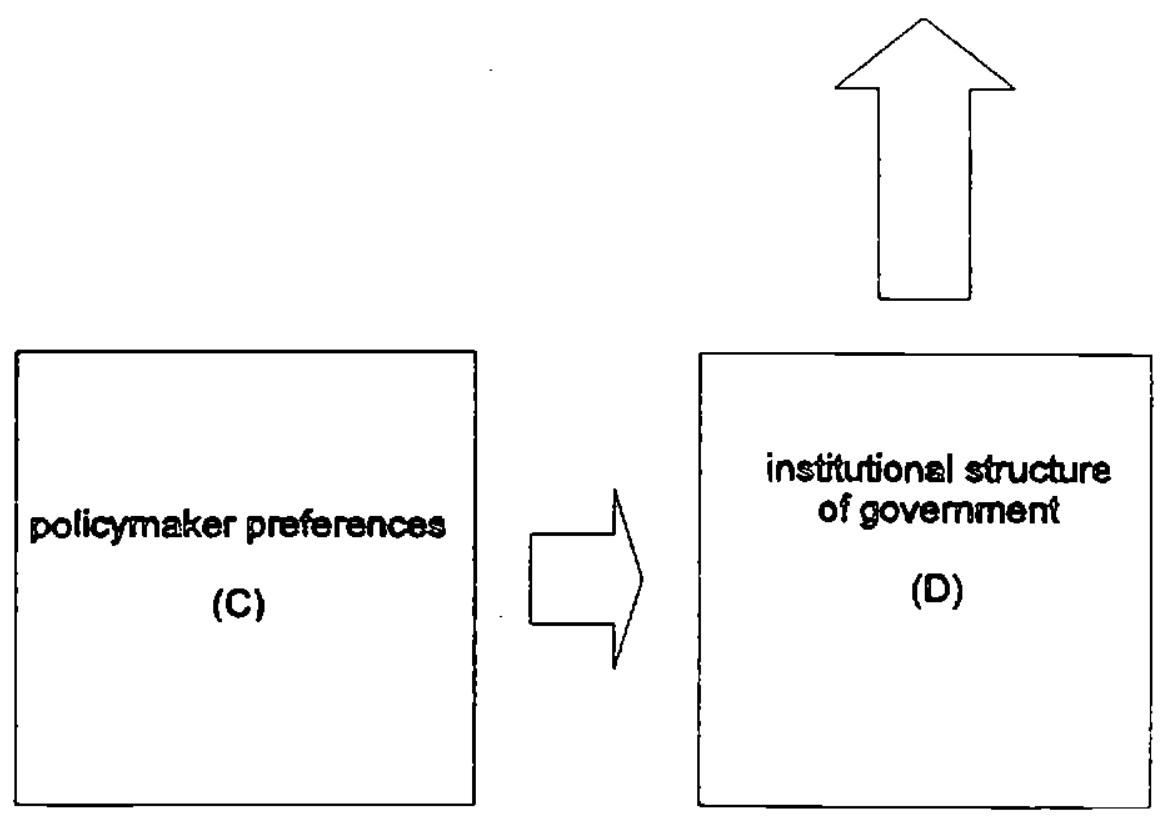

"supply side"
of trade policy

Figure 1 